\title{
Different sequence of high-hydrostatic pressure and mild-heat treatment on the colour and sensory characteristics of strawberry puree
}

\author{
B. Salamon ${ }^{1}$, F. Zakariás ${ }^{2}$, B. Csehi ${ }^{{ }^{*}}$ (1) G. Kiskó ${ }^{2}$ and I. Dalmadi ${ }^{1}$
}

${ }^{1}$ Department of Refrigeration and Livestock Products Technology, Faculty of Food Science, Szent István University, Ménesi út 43-45, H-1118 Budapest, Hungary

${ }^{2}$ Department of Microbiology and Biotechnology, Faculty of Food Science, Szent István University, Somlói út 14-16, H-1118 Budapest, Hungary

\section{ORIGINAL RESEARCH PAPER}

Received: June 16, $2020 \bullet$ Accepted: August 30, 2020

Published online: February 12, 2021

(c) 2020 The Author(s)

\section{ABSTRACT}

The effect of high pressure processing (300 and $600 \mathrm{MPa}$ ) combined with mild heat treatment (55 and $75^{\circ} \mathrm{C}$ ) on the colour parameters, anthocyanin content, and sensory characteristics of strawberry puree were examined after the treatments and 2 weeks of cold storage at 2 and $15{ }^{\circ} \mathrm{C}$. As on an industrial scale the simultaneous implementation of these treatments remains a challenge, the HHP and heat treatments were carried out consecutively in different sequences. The colour parameters and the anthocyanin content did not change significantly due to the treatments, but decreased during cold storage, at $15{ }^{\circ} \mathrm{C}$ storage the changes were more intensive than at $2{ }^{\circ} \mathrm{C}$. Regarding the sensory test results, the different sequence of the $600 \mathrm{MPa}-75^{\circ} \mathrm{C}$ combined treatments is not detectable even after 2 weeks of storage at $15^{\circ} \mathrm{C}$, but in case of $300 \mathrm{MPa}-55^{\circ} \mathrm{C}$, the enzyme inactivation is probably not sufficient enough as differences between the samples were detected.

\section{KEYWORDS}

strawberry, combined treatments, high hydrostatic pressure, sensory analysis, colour, total monomeric anthocyanins

\footnotetext{
*Corresponding author. Tel.: +36 1 3057660; E-mail: Csehi.Barbara@szie.hu
} 


\section{INTRODUCTION}

Strawberries are rich in bioactive compounds, particularly in phenolic compounds and anthocyanins, which have antioxidant properties and can contribute in health prevention. The shelflife of fresh strawberries are relatively short as they are very sensitive to mechanical damage and mould contamination. During transport, processing, and storage they easily lose their sensory qualities (colour, texture, and flavour) (Gao et al., 2016).

HHP processing is a good alternative to substitute heat treatment to preserve food products, as it inactivates vegetative microorganisms, spores, and enzymes as well, thus increases shelf-life, in case of fruits and vegetables up to 4-6 weeks with refrigeration storage (Matser and Timmermans, 2016), while not decreasing sensory qualities and nutritional values of food products (Zabetakis et al., 2000). Additionally, loss of anthocyanins is related to formation of brown pigments, but pressure has minimal effect on anthocyanins, so the product retains its original red colour (Dervisi et al., 2001). HHP alone is not capable of inactivating all enzymes affecting food quality. Residual activity of enzymes, such as peroxidase and polyphenol-oxidase in strawberries generate changes in sensory quality (e. g. browning) and nutritional properties of HHP-treated products during storage (Gao et al., 2016).

HHP combined with mild or high temperatures (called high pressure thermal process, HPT), can produce a sterilisation effect (García-Parra and Ramírez, 2019) and could be applied to preserve low-acid foods (Raso and Barbosa-Cánovas, 2003; Garcia-Parra et al., 2014), and serve as a useful application for heat-sensitive products such as fruit-derived products, and could increase the enzyme inactivation by choosing the suitable combination of treatments (San Martín et al., 2002; Soysal et al., 2004).

Currently HPT treated products are not available on the market (García-Parra and Ramírez, 2019), as there is no such equipment yet available for industrial scale due to engineering and cost efficiency issues. There are many studies investigating HHP and heat treatment, but usually they would be applied simultaneously or compared (Rodrigo et al., 2007; Farkas et al., 2014).

Therefore, the aim of this study was to analyse the effect of consecutive HHP and mild heat treatment on strawberry puree, how the sequence of the treatments affects the colour parameters, anthocyanin content, and sensory qualities.

\section{MATERIALS AND METHODS}

\subsection{Strawberry fruit}

Commercially available quick-frozen strawberries (Fragaria $\times$ ananassa Duch.) were used to produce strawberry puree with a Robot-Coupe C80 type automatic sieve (Robot-Coupe Ltd., Montceau-les-Mines, France) (Farkas et al., 2014). The samples were vacuum packed airtightly in polyethylene (Cryovac $\odot$, BB4L) pouches with an average weight of $50 \mathrm{~g}$.

\subsection{Production and processing of puree}

In these experiments, the applied pressure levels were 300 and $600 \mathrm{MPa}$, combined with 55 and $75{ }^{\circ} \mathrm{C}$ heat treatments (HT). Treatments were carried out consecutively in different sequence (first HHP and after HT or first HT and after HHP). The samples were heat treated at 55 and 
$75{ }^{\circ} \mathrm{C}$ by using a thermostat (Lauda R1225, Germany). The samples were cooled down with icy water after heat treatment. High-pressure experiments were performed in a Resato FPU-1002000 (laboratory scale, Resato International B.V, The Netherlands) high-pressure equipment. The pressure medium was propylene glycol (Resato PG fluid) in the vessel. The initial temperature of the samples was $1-3{ }^{\circ} \mathrm{C}$ (cooled in icy water) and due to the adiabatic heating, the sample's temperature increased by approximately $3{ }^{\circ} \mathrm{C} / 100 \mathrm{MPa}$. The pressure profiles in the sample holder during the treatment were logged. Strawberry purees after treatments were subjected to cold storage at $2{ }^{\circ} \mathrm{C}$ and $15{ }^{\circ} \mathrm{C}$ for two weeks.

\subsection{Colour measurements}

The colour measurements were performed with a Minolta CR-400 (Minolta Co. Ltd., Osaka, Japan) tristimulus colourimeter, in five repetitions. During reflection colour measurement, the three data provided by the instrument are $\mathrm{L}^{*}, \mathrm{a}^{*}$, and $\mathrm{b}^{*}$, which can be used to infer the colour and colour change of the samples. To calculate the total colour difference $\left(\Delta E^{*}\right)$ between different samples, the following equation was used:

$$
\Delta E^{*}=\left[\left(\Delta L^{*}\right)^{2}+\left(\Delta a^{*}\right)^{2}+\left(\Delta b^{*}\right)^{2}\right]^{0,5}
$$

where $\Delta L^{*}, \Delta a^{*}$, and $\Delta b^{*}$ are the differences between the values of $L^{*}, a^{*}$ and $b^{*}$ in the untreated and treated samples (Salamon et al., 2016).

\subsection{Total monomeric anthocyanins (TMA)}

The total monomeric anthocyanin content was determined following the $\mathrm{pH}$ differential method of Giusti and Wrolstad (2001) with some modifications. The measurements were done in triplicate. The phenolic extracts were diluted with $0.025 \mathrm{M}$ potassium chloride buffer $(\mathrm{pH}=1)$ and $0.4 \mathrm{M}$ sodium acetate buffer $(\mathrm{pH}=4.5)$. The absorbances of both solutions were measured each at $520 \mathrm{~nm}$ and $700 \mathrm{~nm}$ by Hitachi U-2900 (Japan) UV-vis spectrophotometer. The concentration of total monomeric anthocyanins in the samples was calculated as mg cyanidin-3glucoside equivalents per litre of fresh puree $\left(\mathrm{mg} \mathrm{L}^{-1}\right)$. The absorbance difference was calculated as:

$$
\operatorname{TMA}\left(\mathrm{mg} \mathrm{L}^{-1}\right)=\frac{\mathrm{A} * \mathrm{MW} * \mathrm{DF} * 1000}{\varepsilon * \mathrm{~L}}
$$

A: absorbance

MW: molecular weight of cyanidin-3-glucoside $\left(\mathrm{mg} \mathrm{mol}^{-1}\right)$

DF: dilution factor

$\varepsilon$ : molar extinction coefficient $\left(26,900 \mathrm{~L} \mathrm{~mol}^{-1} \mathrm{~cm}^{-1}\right)$

L: path length $(\mathrm{cm})$

\subsection{Sensory evaluation}

Sensory analysis was performed by an untrained sensory panel with an average of 32 attendees. The panel evaluated the samples subjected to different HHP and heat treatments by using a triangle test of ISO 4120:2004 (ISO, 2004a), where members were also asked to mark their 
judgements with a reliability index. For the evaluation sequential analysis according to the ISO 16820:2004 (ISO, 2004b) standard was used.

\subsection{Statistical analysis}

Statistical analysis was performed by using SPSS 22.0 for Windows (Chicago, Illinois, USA), applied for differentiation between strawberry samples. Multifactorial analysis of variance (ANOVA) was used to determine the significance and interaction of the experimental parameters (processing, storage). Tukey's multiple range test was used to determine the significance of the differences between the means at a level of significance of $P<0.05$.

\section{RESULTS AND DISCUSSION}

The combined treatments did not change significantly the $\mathrm{L}^{*}, \mathrm{a}^{*}$, and $\mathrm{b}^{*}$ colour parameters compared to the untreated sample $(P>0.05)$, only a slight reduction could be observed in the $\mathrm{L}^{*}$ values, which means the samples minimally lost from their brightness (Fig. 1) In the pairwise comparison of $300 \mathrm{MPa}-55^{\circ} \mathrm{C} / 55^{\circ} \mathrm{C}-300 \mathrm{MPa}$ and $600 \mathrm{MPa}-75^{\circ} \mathrm{C} / 75^{\circ} \mathrm{C}-600 \mathrm{MPa}$ treatments no coherent tendencies could be found between the pairs regarding the sequence of the treatments. After 14 days of cold storage at 2 and $15{ }^{\circ} \mathrm{C}$, in both cases the $\mathrm{L}^{*}, \mathrm{a}^{*}$, and $\mathrm{b}^{*}$ showed significant changes $(P<0.05)$, particularly the values of $\mathrm{a}^{*}$ and $\mathrm{b}^{*}$ decreased. Samples stored at $15{ }^{\circ} \mathrm{C}$ showed more intense reduction than samples stored at $2{ }^{\circ} \mathrm{C}$.

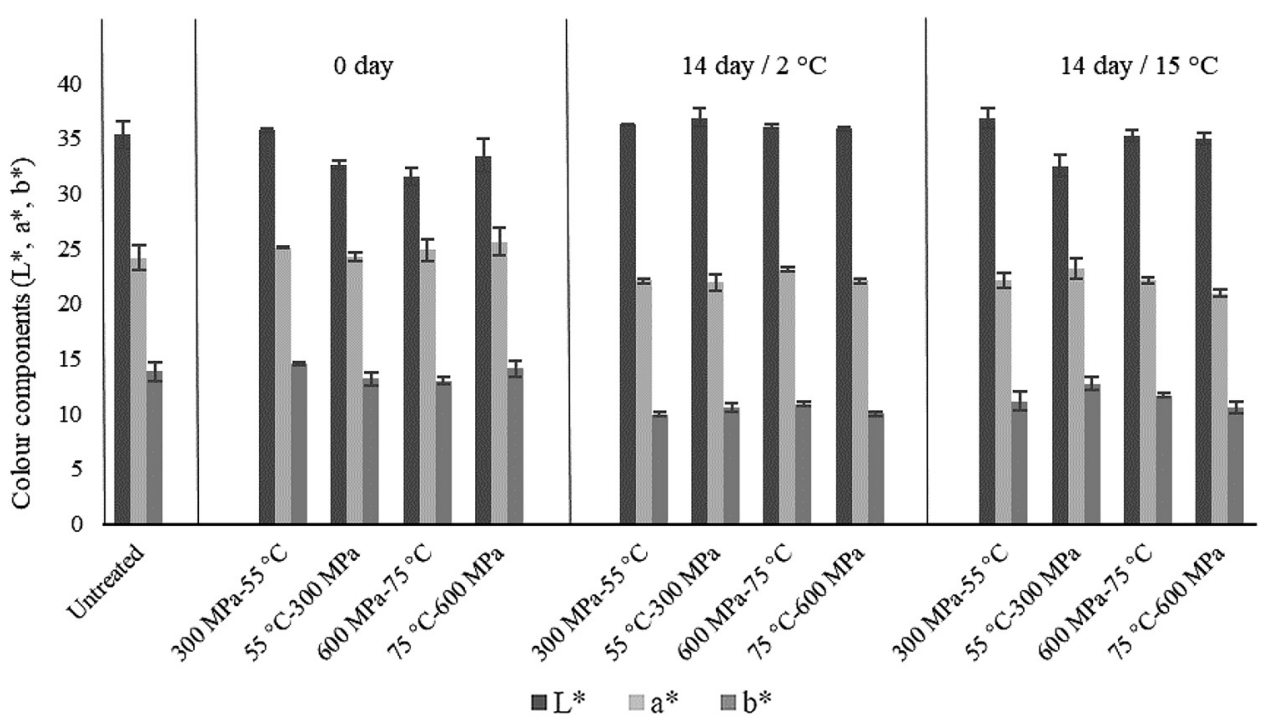

Fig. 1. The effects of combined high pressure-mild temperature processing carried out in different sequence (the first parameter of the combined treatment code always indicates the first treatment, e.g. in case of 300 $\mathrm{MPa}-55^{\circ} \mathrm{C}$ the high pressure treatment was carried out before the mild heat treatment) on the colour components of strawberry puree samples and cold stored at 2 and $15{ }^{\circ} \mathrm{C}$ for 14 days. The error bars represent standard error calculated on the average of five replicate samples 
Pairwise comparison of the lower $\left(300 \mathrm{MPa}-55^{\circ} \mathrm{C}\right)$ and higher $\left(600 \mathrm{MPa}-75^{\circ} \mathrm{C}\right)$ levels of treatments or regarding their sequence show no clear trends after storage at 2 or $15^{\circ} \mathrm{C}$. The data analyses only in case of the $L^{*}$ values approached the significance level $(P \leq 0.05)$.

The examinations of individual colour parameters alone cannot explain whether a difference in colour is perceptible by humans. In order to make easier to obtain general conclusions about colour modifications after processing, the parameter of total colour difference $\left(\Delta E^{*}\right)$ was calculated. Differences in perceivable colour could be estimated such as not noticeable (0-0.5), slightly noticeable (0.5-1.5), noticeable (1.5-3.0), well visible (3.0-6.0), and great (6.0-12.0) (Cserhalmi et al., 2006).

In case of $300 \mathrm{MPa}-55^{\circ} \mathrm{C} / 55^{\circ} \mathrm{C}-300 \mathrm{MPa}$ comparison the $\Delta \mathrm{E}^{*}$ values fell into the well visible category after executing the combined treatments and 14 days of storage at $15{ }^{\circ} \mathrm{C}$, meanwhile in case of the $600 \mathrm{MPa}-75^{\circ} \mathrm{C} / 75^{\circ} \mathrm{C}-600 \mathrm{MPa}$ pair comparison these values were just categorised as noticeable differences (Table 1), which means that due to the higher level of HPT treatments less difference can be noticed between the treated samples. Interestingly, results were the lowest after 14 days of $2{ }^{\circ} \mathrm{C}$ storage, where the differences were not noticeable in either treatment pairs, therefore the storage at lower temperature causes the least colour differences among the samples.

The remaining anthocyanin content results are illustrated in Fig. 2 expressed in percentage compared to the initial untreated sample $\left(268.4 \pm 2.4 \mathrm{mg} \mathrm{L}^{-1}\right)$. Due to the combined treatments

Table 1. Pairwise comparison of the total colour difference of the strawberry puree samples subjected to combined high pressure-mild temperature processing carried out in different sequence and cold storage

\begin{tabular}{lccc}
\hline$\Delta E^{*}$ between pairs & 0 day & 14 days at $2{ }^{\circ} \mathrm{C}$ & 14 days at $15{ }^{\circ} \mathrm{C}$ \\
\hline $300 \mathrm{MPa}-55^{\circ} \mathrm{C} / 55^{\circ} \mathrm{C}-300 \mathrm{MPa}$ & 3.52 & 0.91 & 4.76 \\
$600 \mathrm{MPa}-755^{\circ} \mathrm{C} / 75^{\circ} \mathrm{C}-600 \mathrm{MPa}$ & 2.32 & 1.38 & 1.63 \\
\hline
\end{tabular}

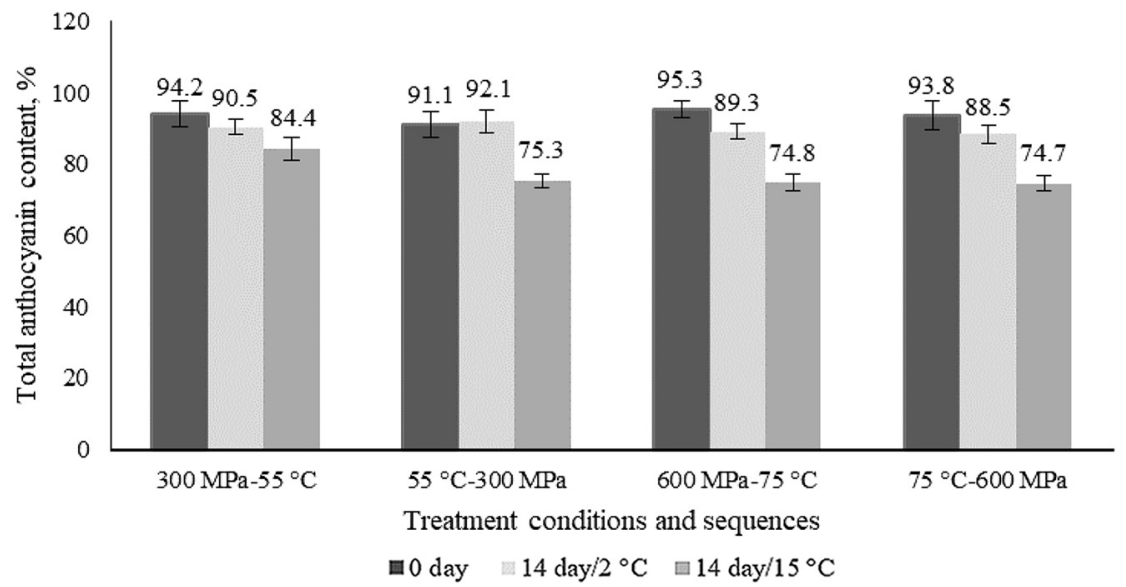

Fig. 2. The effects of combined high pressure-mild temperature processing in different sequence on the total anthocyanin content of strawberries after treatments and cold storage. The error bars represent standard error calculated on the average of three replicate samples 
the anthocyanin content decreased to between 4.7 and 8.9\%. García-Parra et al. (2014) reported similar findings that combined high pressure-mild temperature treatments at $600 \mathrm{MPa}-70{ }^{\circ} \mathrm{C}$ did not affect significantly the anthocyanin content of plum purees. After 14 days of 2 and $15{ }^{\circ} \mathrm{C}$ storage, the rate of the reduction increased up to $7.9-11.5$ and $15.6-25.3 \%$, respectively. Significant reduction in anthocyanin content was observed in strawberry samples treated with 600 $\mathrm{MPa}$ at $60{ }^{\circ} \mathrm{C}$ for $10 \mathrm{~min}$ during refrigerated storage by Terefe et al. (2009).

In the pairwise comparison of $300 \mathrm{MPa}-55^{\circ} \mathrm{C} / 55^{\circ} \mathrm{C}-300 \mathrm{MPa}$ and $600 \mathrm{MPa}-75^{\circ} \mathrm{C} / 75^{\circ} \mathrm{C}-600$ $\mathrm{MPa}$ treatments no significant changes occurred $(P>0.05)$, the sequence of the HHP and TP did not affect marginally the anthocyanin content of the strawberry puree samples. After 14 days of cold storage, comparison results of lower and higher levels of treatments showed slightly lower anthocyanin content in the samples treated with the higher level of parameters, but this difference was not significant $(P>0.05)$. Regarding storage temperature, at the higher temperature of cold storage the anthocyanin content of the strawberry purees were significantly lower $(P<$ $0.05)$.

In Fig. 3 the results of the pairwise sensory tests are shown. Immediately after the treatments in case of the $300 \mathrm{MPa}-55^{\circ} \mathrm{C} / 55^{\circ} \mathrm{C}-300 \mathrm{MPa}$ samples, the line of the total correct answers did

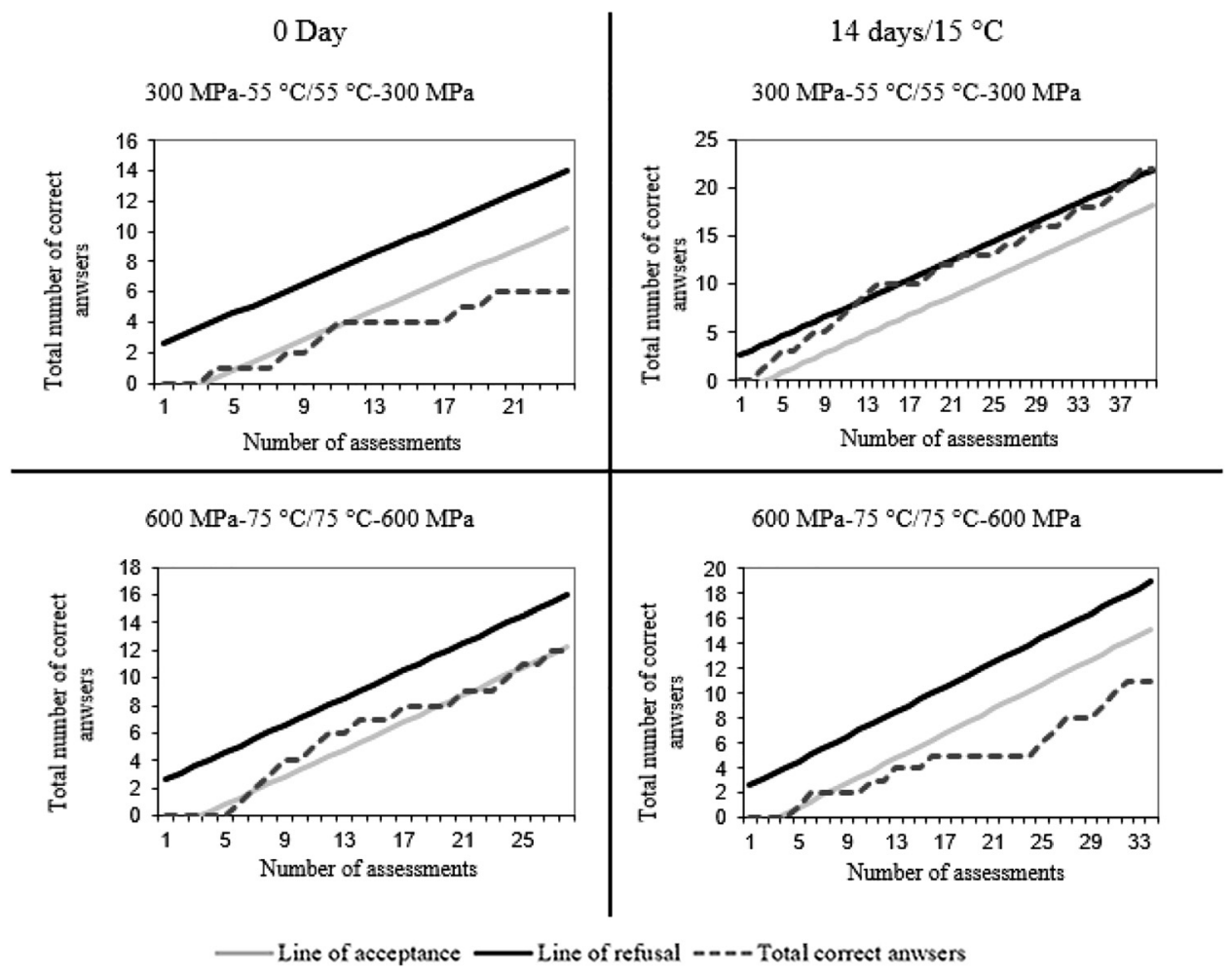

Fig. 3. Sensory quality results of the triangle tests between pairs of strawberry puree samples treated with combined HHP and HT in different sequence and after cold storage 
not approach the rejection limit but rose together with the acceptance limit initially and later remained continuously below it, which means there was no significant difference $(P=0.736)$ between the samples.

Marszałek et al. (2015) also found that colour, taste, aroma, and consistency values of all samples treated with $500 \mathrm{MPa}$ of $\mathrm{HPP}$ at $50{ }^{\circ} \mathrm{C}$ showed no significant differences compared to the fresh samples.

In case of $600 \mathrm{MPa}-75^{\circ} \mathrm{C} / 75^{\circ} \mathrm{C}-600 \mathrm{MPa}$ samples similar results were obtained with less confidence, probably more intensive changes happened due to the higher level of parameters $(P=0.103)$.

The line of correct answers approached the line of the rejection limit for pairs $300 \mathrm{MPa}-55$ ${ }^{\circ} \mathrm{C} / 55{ }^{\circ} \mathrm{C}-300 \mathrm{MPa}$ after 14 days of storage at $15{ }^{\circ} \mathrm{C}$. With this trend, involving more panellists, the line would presumably cross and get continuously further from the rejection limit, which means difference can be detected between the samples, also confirmed by the statistical analysis $(P=0.001)$. The lower level of treatments probably did not sufficiently inactivate the enzymes, which worked continuously during the 2 weeks of storage, thus causing sensory changes in the product. On the contrary, $600 \mathrm{MPa}-75^{\circ} \mathrm{C} / 75^{\circ} \mathrm{C}-600 \mathrm{MPa}$ pair comparison after 14 days of $15^{\circ} \mathrm{C}$ storage showed no difference $(P=0.467)$ between the samples.

Application of higher pressure and temperature parameters likely inactivated the enzymes to a greater extent and more intensively reduced the number of germs, resulting in minimal change in the sensory characteristics (García-Parra et al., 2014; Terefe et al., 2016).

\section{CONCLUSIONS}

It can be stated that due to the application of combined high pressure and mild temperature treatments in different sequences no significant changes could be detected between the sample pairs of $300 \mathrm{MPa}-55{ }^{\circ} \mathrm{C} / 55{ }^{\circ} \mathrm{C}-300 \mathrm{MPa}$ and $600 \mathrm{MPa}-75^{\circ} \mathrm{C} / 75^{\circ} \mathrm{C}-600 \mathrm{MPa}$ in terms of their colour parameters, anthocyanin content, and sensory characteristics. However, significant changes happened during the cold storage. The $L^{*}$ values slightly decreased and the samples lost from their brightness. The total colour difference values show that changes are lower in case of higher level of treatment parameters $\left(600 \mathrm{MPa}, 75^{\circ} \mathrm{C}\right)$ and at lower temperature of cold storage $\left(2{ }^{\circ} \mathrm{C}\right)$. Also higher anthocyanin content remained after cold storage at $2{ }^{\circ} \mathrm{C}$. According to the sensory evaluation, there were no detectable changes regarding the application sequence of the combined $600 \mathrm{MPa} \mathrm{HHP}$ and $75{ }^{\circ} \mathrm{C} \mathrm{TP}$ treatments, even after 14 days of storage at $15^{\circ} \mathrm{C}$. In case of application of lower parameters such as $300 \mathrm{MPa}$ and $55{ }^{\circ} \mathrm{C}$, difference could be detected among the samples. Further examinations are recommended to sort out which other quality attributes play important role in these changes and establish their threshold of treatment parameters.

\section{ACKNOWLEDGEMENT}

This research was supported by the Ministry for Innovation and Technology within the framework of the Higher Education Institutional Excellence Program (NKFIH-1159-6/2019) in the scope of plant breeding and plant protection researches of Szent István University and the 
Hungarian Ministry of Agriculture; European Union and co-financed by the European Social Fund (Grant No. EFOP-3.6.3-VEKOP-16-2017-00005).

\section{REFERENCES}

Cserhalmi, Z., Sass-Kiss, Á., Tóth-Markus, M., and Lechner, N. (2006). Study of pulsed electric field treated citrus juices. Innovative Food Science and Emerging Technologies, 7: 49-54.

Dervisi, P., Lamb, J., and Zabetakis, I. (2001). High pressure processing in jam manufacture: effects on textural and colour properties. Food Chemistry, 73: 85-91.

Farkas, V., Dalmadi, I., and Balla, Cs. (2014). Effect of high hydrostatic pressure treatment on volatiles of berry purées. Acta Alimentaria, 43: 51-57.

Gao, G., Ren, P., Cao, X., Yan, B., Liao, X., Sun, Z., and Wang ,Y. (2016). Comparing quality changes of cupped strawberry treated by high hydrostatic pressure and thermal processing during storage. Food and Bioproducts Processing, 100(Part A): 221-229.

García-Parra. J., González-Cebrino. F., Cava. R., and Ramírez, R. (2014). Effect of a different high pressure thermal processing compared to a traditional thermal treatment on a red flesh and peel plum purée. Innovative Food Science and Emerging, 26: 26-33.

García-Parra, J. and Ramírez, R. (2019). New preservation technologies: hydrostatic high pressure processing and high pressure thermal processing. In: Ferranti, P., Berry, F., and Jock, A. (Eds.), Encyclopedia of food security and sustainability, Vol. 2. Elsevier, pp. 473-480.

Giusti, M.M. and Wrolstad, R.E. (2001). Characterization and measurement of anthocyanins by UV-visible spectroscopy. Current Protocols in Food Analytical Chemistry, F1.2.1-F1.2.13.

ISO. (2004a). Sensory analysis - methodology-triangle test. ISO 4120:2004.

ISO. (2004b). Sensory analysis - methodology - sequential analysis. ISO 16820: 2004.

Marszałek, K., Mitek, M., and Skạpska, S. (2015). The effect of thermal pasteurization and high pressure processing at cold and mild temperatures on the chemical composition, microbial and enzyme activity in strawberry purée. Innovative Food Science and Emerging, 27: 48-56.

Matser, A. and Timmermans, R. (2016). High-pressure effects on fruits and vegetables. In: Balasubramaniam, V.M., Barbosa-Cánovas, G.V., and Lelieveld, H.L.M. (Eds.), High pressure processing of food principles, technology and applications, 1st ed. Springer, New York, USA, p. 549.

Raso, J. and Barbosa-Cánovas, G.V. (2003). Nonthermal preservation of foods using combined processing techniques. Critical Reviews in Food Science and Nutrition, 43: 265-285.

Rodrigo, D., van Loey, A., and Hendrickx, M. (2007). Combined thermal and high pressure colour degradation of tomato puree and strawberry juice. Journal of Food Engineering, 79: 553-560.

Salamon, B., Tóth, A., Palotás, P., Südi, G., Csehi, B., Németh, Cs., and Friedrich, L., (2016). Effect of high hydrostatic pressure (HHP) processing on organoleptic properties and shelf life of fish salad with mayonnaise. Acta Alimentaria, 45: 558-564.

San Martín, M.F., Barbosa-Cánovas, G.V., and Swanson, B.G. (2002). Food processing by high hydrostatic pressure. Critical Reviews in Food Science and Nutrition, 42: 627-645.

Soysal, C., Söylemez, Z., and Bozoğlu, F. (2004). Effect of high hydrostatic pressure and temperature on carrot peroxidase inactivation. European Food Research and Technology, 218: 152-156. 
Terefe, N.S., Matthies, K., Simons, L., and Versteeg, C. (2009). Combined high pressure-mild temperature processing for optimal retention of physical and nutritional quality of strawberries (Fragaria $\times$ ananassa). Innovative Food Science and Emerging, 10: 297-307.

Terefe, N.S., Tepper, P., Ullman, A., Knoerzer, K., and Juliano, P. (2016). High pressure thermal processing of pears: effect on endogenous enzyme activity and related quality attributes. Innovative Food Science and Emerging, 33: 56-66.

Zabetakis, I., Koulentianos, A., Orruño, E., and Boyes, I. (2000). The effect of high hydrostatic pressure on strawberry flavour compounds. Food Chemistry, 71: 51-55.

Open Access. This is an open-access article distributed under the terms of the Creative Commons Attribution 4.0 International License (https://creativecommons.org/licenses/by/4.0/), which permits unrestricted use, distribution, and reproduction in any medium, provided the original author and source are credited, a link to the CC License is provided, and changes - if any - are indicated. (SID_1) 